\title{
ЗОБРАЖУВАЛЬНИЙ І ВИРАЖАЛЬНИЙ АСПЕКТИ НАРАТИВУ ЩОДЕННИКА ДОКІЇ ГУМЕННОЇ
}

У статті вперше проаналізовано текстове наповнення щоденника Д. Гуменної, зображувальний $i$ виражальний компоненти з позииій наратології, розділу літературознавства, об 'єктом дослідження якого є теорія оповіді. Здійснено спробу аналізу структурної організаџії щзоденника, а також діалогічної взаємодії автор / читач, щзо надає змогу об'єктивно оцінювати результати творчої роботи мемуариста. Доведено, щзо в тексті взаємодіють автор $i$ реципієнт, прочитуються інтерпретації оповідача (мемуариста) і сприйняття його думки реципієнтом.

Ключові слова: наратор, інтерпретація, діаріуш, оповідь, рефлексивність, автор, читач.

В статье впервые проанализировано текстовое наполнение дневника Д. Гуменной, изображающий $и$ выражающий компоненты $c$ позиций наратологии, раздела литературоведения, объектом исследования которого является теория рассказа. Осуществлена попытка анализа структурной организачии дневника, а также диалогического взаимодействия автор / читатель, что дает возможность объективно оценивать результаты творческой работь мемуариста. Доказано, что в тексте взаимодействуют автор и реципиент, прочитываются интерпретации рассказчика (мемуариста) и восприятие его мысли рециипиентом.

Ключевые слова: наратор, интерпретация, диариуш, рассказ, рефлексивность, автор, читатель.

For the first time the text filling of D. Humenna's diary, pictorial and expressive components from the standpoint narratology, section of literary studies, which object of the research is the theory of narration, have been analyzed in the article. There was an attempt to analyze the structural organization of the diary, as well as dialogical interaction of the author / 
reader that provides the opportunity to objectively assess the results of the creative work of the memoirist. It is proved that the author and the recipient interact in the text, the interpretations of the narrator (the diarist) and the perception of her thoughts by the recipient can be seen.

Keywords: narrator, interpretation, diariush, narration, reflexiveness, author, reader.

Постановка проблеми. Чверть століття минуло, як в новітню «материкову» літературу почали повертатися із забуття імена талановитих митців, котрі створювали духовні скарби за межами Батьківщини, в еміграції. У добу панування соцреалізму, заборон та беззаконня тоталітарного режиму 3 національного культурного життя було викреслено творчість еміграційних письменників. За часів незалежності України ситуація в літературознавстві кардинально змінилася, зокрема захищено чимало дисертаційних робіт, в яких науково трактується художня спадщина письменників, котрі творили за межа Україною. На сьогоднішній день історія української літератури поповнилась науковими розробками, монографіями, авторами яких є відомі літературознавці В. Панченко, І. Руснак, В. Гуменюк, Л. Тарнашинська, В. Мацько, Н. Баштова, Ю. Григорчук, Я. Нагорний, Н. Швець та ін. Водночас зауважимо, що світоглядний обшир Д. Гуменної, який простежується у іiі літературній мемуаристиці, ще не знайшов широкого аналізу. Письменниця пройшла складний творчий шлях, відтак проблемність теми розкривається крізь призму зображення художньо-естетичних конфліктів, пошуках власного творчого «я», своєї особливої світоглядної позиції. Такі аспекти творчості мемуариста залишаються поза науковою рефлексією, тим більше, що щоденники письменниці в яких виразно трансформовано світоглядні домінанти автора, ще не стали об’ єктом пильної зацікавленості дослідників.

Аналіз досліджень і публікаџій, в яких започатковано розв'язання даної проблеми. В українському літературознавстві художня творчість письменниці української діаспори стала предметом дослідження у працях Г. Костюка [Костюк 1978], Ю. Шереха (Шевельова) [Шерех 1993], А. Погрібного [Погрібний 1994], М. Мушинки [Мушинка 1993], В. Мацька [Мацько 2010], П. Сороки [Сорока 2003], В. Даниленка [Даниленко 2000], О. Коломієць [Коломієць 2006], Т. Николюк [Николюк 2009]. 
У різний час аналізували твори Д. Гуменної еміграційні дослідники Ю. Бойко, В. Державин, Б. Романенчук, О. Чернова, Ю. Миколин, В. Чапленко, А. Юриняк, Лада Горлиця (О. Костюк), Н. Іщук-Пазуняк. Проблемно-тематичні та жанрово-стильові особливості іiі прозописьма розглядали М. Васьків, В. Жила, Л. Дражевська, Л. Онишкевич та ін. Однак і досі існує певна потреба у створенні аналітичних праць, які б розкривали не лише біографію, особливості творчості, а й давали уявлення про багатий внутрішній світ письменниці, iї погляд на своє місце у світі.

Meта статmі полягає у спробі науково обгрунтувати зображувальний i виражальний аспекти наративу в щоденнику Докії Гуменної.

Виклад основного матеріалу. Д. Гуменна усе життя занотовувала події минулого. Саме так, бо діаріуш характеризується записами минулого часу. Те, що відбувалося з автором перед записом - це хоч і недалекий, але минулий проміжок часу. Ці записи - спосіб самовираження письменниці, розмови із собою.

Працюючи над тематичною проблематикою, ми зауважили, що наративні особливості щоденникових записів виявляються через використання Д. Гуменною наступних прийомів: ретрадація, одивнення, іронія, цитування, перифраз, стилістичні фігури (підключення уяви читача), алюзія, риторичні речення, ремарки. Матриця щоденників прочитується в кількох модифікаціях суспільно-побутовій, суб'єктивно-психологічній та просторовій (подорожній діаріуш). Датування стає неодмінним атрибутом, авторка фіксує не лише число, місяць і рік, а й день тижня, місцями - точну годину запису. Відтак час побудовано за лінійною концепцією. Оскільки мемуарист постійно звертається до щоденника, його ведення стає регулярною справою, умовою життя, а тому часові межі місцями помітно звужуються, записи охоплюють період від одного до трьох, іноді - до семи-восьми днів. На нашу думку, до щоденникових записів письменницю мотивували такі принципи: творчий характер; наявність зорових (слухових) сприйнятих реальних матеріалів для зображувальної діяльності та їх інтерпретація; модерація (регулювання) установки на 
саморозвиток та особисту орієнтацію щодо активного творчого розвитку. А поява інтересу - це передумова i своєрідний показник художньої досконалості, засіб підвищення ефективності зображувальної діяльності. Формування авторського інтересу до ведення щоденника, за визначенням психологів, вказує на незачинений в собі автономний процес. С. Рубінштейн завважує: «... Свою об’єктивну змістовність психологія людини та ї діяльність черпають із ставлення людини до іншої людини, до суспільства... Суспільне ставлення до інших людей опосередковується в людині, ї̈ ставленні до природи, взагалі до об’єкта. Людина існує як людина лише завдяки своєму ставленню до іншої людини» [Рубинштейн 1973:51]. Отже, людина поза суспільством не існує, особистість цікавиться довкіллям, як і занурюється у власний світ.

У процесі дослідження простежується і той факт, що зошити Д. Гуменної яскраво демонструють такі моделі:

а) класичний щоденник, в якому продемонстровано публіцистичну нарацію з чітко вираженою активізацією авторського «я»;

б) діаріуш із послабленим проявом суб'єктивного авторського фактора, в якому знаходимо характерні ознаки опосередкованої, презентативної моделі оповіді;

в) щоденник, який носить характер літературно-художнього тексту i в якому прочитується активна белетризована позиція автора.

Означені моделі, однак, класифікуються за різним функціональним ступенем. Наприклад, у класичному щоденнику панівне місце посідає суб'єктивно-психологічне мотивування, тоді як в опосередкованому, презентативному діаруші - соціально-історичне, а в літературно-художніх записах переважають естетичні мотиви.

У щоденниках Д. Гуменної життя постає таким, яким вона його бачила упродовж XX століття, яким сприймала його внутрішнім єством, сформованим світоглядом. Американський психолог Джером Брунер розглядає життя як наратив. Свою думку він теоретично обгрунтовує так: «Наратив імімує 
життя, життя імітує наратив. Відтак «життя» $є$ таким же різновидом конструкиії людської уяви, щзо і наратив. Воно сконструйовано людьми за допомогою активного раціоналізування, саме того ращуіналізування, за допомогою якого ми конструюємо наративи. Коли нам хтось розповідає своє життя - ие завжди швидие результат когнітивних операцій, ніж якесь сповідування крізь прозоре скло про щцось, яке оповідач подав у єдиному описі. В решті-решт, иче розумово-фізична дія опису, мистецтвво інтерпретацї. У ставленні до психологї немає такої речі як «життя само по собі». Щонайменше, изе - результат вибіркової роботи пам'яті; крім того, виклад будь-якого життя - изе мистецттво інтерпретаціï» [Bruner 1987:12].

Передача інформації суб'єктивується наративними функціями, компонентами. Наративна функція культури в літературному щоденнику спрямовує нас до найголовнішої інстанції, якою є поняття наративу та його функцій, особливо, коли компоненти свідомості наратора розпорошені в розповіді. Отже, в англійській мові існує слово narrative - «розповідь», яка відображає суть наративної концепції, останні представлено в різних галузях гуманітаристики: філології, психології, соціології, філософії, культурології. Наратив різниться від простої розповіді тим, що розповідь, розмова - це звичайний спосіб комунікації, спосіб отримання й передачі інформації, тоді як наратив, за термінологією Артура Данто «пояснює розповідь» [Данто 2002:194]. Наратив слід сприймати не як об’єктивну, а суб’єктивну розповідь. Таку модель репрезентує щоденник: у звичайну розповідь про події, факти дня Д. Гуменна часто вкраплює суб’єктивні емоції, оцінки для того, щоб не просто подати інформацію, констатувати факти, а передовсім справити певне враження, зацікавити, змусити майбутнього читача діаріуша проявити емоційну реакцію, естетичне переживання. Рецептивна константа прочитується в залученні до структури тексту індивідуальних нараторських оцінок й емоцій оповідача. Так, Д. Гуменна 3 лютого 1950 р. занотувала власне ставлення до світу через екзистенційне «я» в емоційному вираженні: «Моя постійна думка працює, розвиває свою концепцуію. Не все чомусь втілюється в слова. Але вона є $i$ зовсім 
відмінна від усього - оточення, способу їх мислення, всіх філософських систем... Та упорядкувати ї̈ щее не можу. Все було щзось у мене неясне, необдумане з 13-ти років. Тепер уже додумане. ... Зовсім не жаль, не страшно, як тобі (мені) не попадає всього того, щуо іншим. Його мені не треба. Що мение, то кращче...

... Щоб мати право просити щуось у Бога, треба перейти на сіль $і$ воду» [2, арк. 107].

Унаочнений текст переконує нас в тому, що структура наративу неоднозначна, форми його нестабільні, відтак взагалі не може існувати будьяких зразків форми, тобто в залежності від контексту ситуації вони сповнені індивідуальним змістом. Отже, контекст (дискурс), в якому втілюється наратив, є центральною частиною його існування. Ми взяли в дужки дискурс, який в широкому розумінні втілений у мові. Тобто, дискурс - це мовна діяльність і іï процес. Відповідно до парадигми постмодерністів, наратив $є$ дискурсивною реальністю, яка в ньому і розкривається. Й. Брокмейєр розглядає наратив як «nідвид дискурсу» [Брокмейер 2000:31], тому, з точки зору лінгвістики та літературознавства, дефініції наратив i дискурс ми розуміємо як такі, що $\epsilon$ невіддільні одна від одної, але існують паралельно. Теоретик літератури Р. Гром’як зауважив, що «в украӥнській традищї здавна побутують два терміни для позначення передачі інформащї від однієї особи до іншої чи повідомлення для групи слухачів: оповідь (оповідка, оповідання) $i$ повість (повістка, оповість). Вже за часів I. Франка лексема «оповідання» передавала категорії дієслова та іменника: оповідання як процес повідомлення про пригоди, подї, переживання завершується результатом - оповіданням, щзо має певну мовленнєво-мовну структуру (текст)» [Гром’як 2005:11].

В діаріуші Д. Гуменної наратив має вагоме значення для прочитання, характеристики літературно-художнього тексту, в якому увиразнюється активна белетризована позиція автора. У тексті взаємодіють автор і читач, прочитуються інтерпретації оповідача (мемуариста) і сприйняття його думки реципієнтом. Письменниця 30 жовтня 1949 р. занотувала: «Прийшло мені на 
думку записати пісні, щуо відбивають матріархат в сучасній украӥнській дійсності, в тій галузі, де вона (мати. - Т.Ш.) панувала $і$ зосталась неподільно господинею, і моральній. Майже ні одна життьова ситуація не обходиться без матері. В якого народу щзе так? Згадуються деякі пісні, як [,] наприклад, «Дозволь мені, мати, криницюю копати», «Огірочки», «Ой, дуб, дуба, дуба, дуба...», "Ясна зірка сяє, мати дочку лає», «Ой ти мати, пораднице в хаті». Ця тема - непочатий край. Тут тільки несміливий початок...» [Щоденник: арк. 89].

Тут авторка наче веде діалог із собою, власним «я», але це власне «я» спроектовано на «іншого», тому слушною є думка М. Ткачука про те, що саме оповідач розгортає діалог між собою та своїм реципієнтом у парадигмі тексту літературного твору [Ткачук 2005:148-149]. Однак, додамо, що авторка в проілюстрованому тексті не лише розгортає діалог, а й вкладає певну інформацію для читача, особливо для сучасного дослідника пісенного фольклору. Необізнаний читач сприйме запис Д. Гуменної як звичайну історичну інформацію про минуле життя українців, обізнаний - мислено зануриться в минувшину, проінтерпретує пісні 3 наукової точки зору, переосмислить їх і трансформує, відповідно до світоглядного бачення, у свій внутрішній світ, розширивши знання тим, що відшукали українські пісенники, прочитає текст, проаналізує його. Таким чином, створюючи текст, мемуарист вкладає в нього певну інформацію, яка, пройшовши тривалий шлях до читача, під кутом зору останнього може абсолютно змінитися або бути інакше трактована. Для того, щоб правильно дешифрувати авторські інтенції, мусимо повністю прочитати щоденник, врахувати присутність інших осіб, оцінну функцію мемуариста, розкрити присутність автора-оповідача й майбутнього читача, на кого й розрахований текст, тобто виявити власне функції наратора / читача. В процесі дослідження нами виявлено, що оповідач наповнює текстову структуру риторичними реченнями, які $\epsilon$ неоднозначними, зокрема думка автора може не збігатися 3 думкою читача, риторика сповнена різними смислами, відтак залишає реципієнтові простір для роздумів. Такий 
індивідуальний стиль притаманний творчим людям i $\epsilon$ важливою ознакою яскравого виокремлення чи чіткого виявлення в щоденнику літературнохудожніх текстів.

Нині студентське середовище все більше використовує комп'ютерну техніку, яка не завжди сприяє правильному формуванню мислення, адже для підтвердження даних необхідно звертатися і до архівних джерел, до друкованої продукції чи рукописів, бо правильне (справжнє) мислення, його ефективність визначається за законами індукції (логіки), а не за законами редукування (спрощення) механічної чи електронної техніки. Аргументуючи індукцію, маємо на увазі щоденникові записи Д. Гуменної, яка викладає життя в автобіографічному ключі. Діаріуш автора представляє конструктивістські наративи, в яких прочитується центральна думка про те, що світ $\epsilon$ основоположною функцією мозку людини. Особистість пізнає довкілля й подає його в описах. Інша форма нарації побутує в конструктивістській формі, коли автор торкається автобіографічних елементів. Постає своєрідна дилема у розповіді про себе: авторка нарікає на історичні фактори розвитку, іноді вдається до критики нації своєї і чужої, не усвідомлюючи, що історичні епохи в реальному світі самі собою не постають, спершу «історію» творять особистості у формі ідей, конструюють їх розумово (обмірковують), і лише потім втілюють ідеї на практиці. Звідси постає історична роль особистості. Ми вважаємо, що справедливіше було б для автора, перш ніж звинувачувати «іншого» в гріхах, проаналізувати власне «я» і його роль в суспільних процесах. Повертаючись до симетрично протиставної думки Д. Брунера, який сказав, що наратив імітує життя, життя імітує наратив, зауважимо, що для читача сприйняти автобіографізм як прожитий час (lived time) виявиться складною справою, якщо він не зважатиме на дилеми конструктивістських наративів.

Образ автора у власній біографії ми розглядаємо як сконструйований запис-інтерпретацію / реінтерпретацію набутого досвіду, як історію власного життя-наративу (життя імітує наратив), адже мікро / макро історія належить світові. Створивши власний світ у собі, письменниця у щоденнику занотовує 
свій погляд і на світ зовнішній, який прочитуємо в автобіографічному ключі. Реципієнт, вчитуючись в автобіографію (формальну чи неформальну), навіть якщо при цьому проявлятимуться ознаки складної дилеми, спонуки суб’єктивізму, дешифрує життя, що його «імітує наратив» (Д. Брунер). Архітектор когнітивної революції Д. Брунер у праці «Можливі світи» (Кембридж, 1986), виклав теорію нарації в аспекті поєднання комплексу літературознавчих, лінгвістичних, антропологічних концепцій й розглядає психічні акти під час написання художнього (уявного) світу, спроектовуючи аналіз досліджень на вивчення психіки людини, іiі почуття, свободу творчого мислення. Реально сконструйований (написаний) автором твір психолог називає «режимом оповіді», простором наратора, в якому повною мірою розкривається його природа.

У багаторічних щоденникових записах Д. Гуменної в повному обсязі постає історія власного життя, що його пізнаємо не так привілейованим, як проблемним наративом, бо в ньому прочитується рефлексія: i наратор, i центральна фігура наративу поєднані, ідентичні, що знову ж таки створює колізію дилеми. Преференції «знеособлення» сприймається читачем насторожено, оскільки письменник у такий спосіб створив собі літературний «пам’ятник» чи суб’єктивними розмислами про інших осіб (а таких роздумів $\epsilon$ чимало в щоденнику), колег по перу, створює, образно кажучи, атмосферу «нескінченної прелюдії», яка призводить до небажаної похибки наратораоповідача автобіографії, позаяк суб’єктивний оцінний фактор детермінований із зовні. Відтак рефлексивність самоопису віддзеркалює проблему, що виходить за рамки іншої проблеми індетермінованості, тобто перебільшенням власного «я» в поліаспектній історії цивілізації та розповіді про неї, видобутої з криниці пам'яті наратора. Таким чнном, порушена проблема виходить за рамки раціонального мислення. Подібний текст читач сприйматиме не активно, пропускатиме крізь свою свідомість як індиверентний, не ідеальний. Тут наштовхуємось на умовний «конфлікт» автор / читач, який психологи трактують 3 точки зору співвідношення суб’єкт / об’єкт. Характер 
взаємозв’ язків між ними тісно переплетений, адже «будь-який конфлікт несе в собі цілий комплекс об'єктивно-суб'єктивних причин. Тобто більшість об'єктивних причин певною мірою є суб'єктивними, а більшість суб'єктивних причин конфліктів - об'єктивно детерміновані. Збереження стабільного рівня депривації (гальмування) можливе при зниженні рівня запитів, або прискореному зростанні задоволення перед ростом сподівань» [Динаміка конфлікту і механізми його розвитку [Електронний ресурс].

Однак в цьому умовному «конфлікті» інтересів автора / реципієнта є позитивний момент, який виражає захоплюючими сторінками розповіді про життя-буття, як звіт мемуариста перед читачем. I хоч ці звіти іноді видаються нестабільними, уривчастими (у щоденнику автор сам собі розповідає), а все ж така нестабільність уможливлює спроектувати оповідь на міжперсональні, лінгвістичні і культурологічні впливи їх сприйняття. Тоді такі жваві оповіді, оповиті зображально-виражальними засобами, стають «ліками» для душі, несуть естетичну насолоду, роблять життя цікавішим. Позитивні зміни у застосуванні мовно-виражальних засобів, художньо обрамленого опису життя індивіда прикрашають не лише текст, а й випромінюють естетичну насолоду для читача.

Отже, щоденник (щоденникові зошити) Д. Гуменної віддзеркалюють своєрідну сповідь перед читачем про власне життя. Відомо, що ведення щоденника $є$ давньою і універсальною формою, яка виражена і сформульована відповідно до авторського задуму в культурній, лінгвістичній, образотворчій i наративній формах. Зміст і форма нотаток змодельовані відповідно до історичних та суспільних обставин, які «уживлені» в культуру і мову автора, але, як свідчать вище наведені нами теоретичні обгрунтування, при цьому форма має вагоміше значення в структурі діаріуша, ніж зміст. I хоча за жанровою ознакою щоденник відносять до документалістики, до «форми самовираження письменника» (К. Танчин), все ж, вважаємо, що автор від звичайного переказу побаченого чи почутого, повинен перейти до викладу тексту не буденною, трафаретною мовою, а живою, соковитою, 3 
використанням різних елементів тропеїзації, символізації. Означені критерії впливають на зображувальний i виражальний аспекти наративу в щоденнику Д. Гуменної. Повторимось, що образ автора у власній біографії ми розглядаємо як сконструйований запис-інтерпретацію / реінтерпретацію набутого досвіду, як історію власного життя-наративу (життя імітує наратив), адже мікро / макро історія належить світові. Створивши власний світ у собі, письменниця у щоденнику занотовує свій погляд на зовнішній світ, який прочитуємо в автобіографічному ключі.

\section{БІБЛІОГРАФІЯ}

Брокмейер 2000 - Брокмейер Й. Нарратив: проблемы и обещания одной альтернативной парадигмы / Йен Брокмейер, Ром Харре // Вопросы философии. - 2000. - №3 - С. 29-42.

Відділ рукописних фондів і текстології Інституту літератури імені Т. Г. Шевченка НАН України / Щоденники Докії Гуменної. - Ф. 234. Од. зб. 14. - Оп. 1. - 111 арк.

Гром’як 2005 - Гром’як Р. Проблема включення українських традицій в сучасну наратологію / Наративні виміри літератури. Матеріали міжнародної конференції з наратології / Роман Гром'як // Studia methodologica. Вип. 16. Тернопіль : Редакційно-видавничий відділ ТНПУ, 2005. - С. 10-19.

Даниленко 2000 - Даниленко В. Ідеалізм і авторитарний тип особистості (за повістю Докії Гуменної «Мана») / Володимир Даниленко // Слово і час. 2000. - №5. - C. 38-41.

Данто 2002 - Данто А. Аналитическая философия истории. Перевод с англ. А. Л. Никифорова, О. В. Гавришиной / Артур Данто. - М. : Идея-Пресс, 2002. -292 c.

Динаміка конфлікту і механізми його розвитку [Електронний ресурс] / Режим доступу : http://pidruchniki.com/18111210/psihologiya/dinamika konfliktu_mehanizmi_rozvitku - Дата звернення : 15.05.2016.

Коломієць 2006 - Коломієць О. В. Проза Докії Гуменної (проблемнотематичні та жанрово-стильові особливості) : дис... канд. філол. наук: 10.01.01 / 
Київський національний ун-т ім. Тараса Шевченка. Інститут філології. - К., 2006. - 176 арк.

Колядина А. Дневник как литературній жанр / Анна Колядина [електронний ресурс] / Режим доступу : http: // lit.1september.ru/article.php? $\mathrm{ID}=200601914$. - Дата звернення : 21.04.2016.

Костюк 1978 - Костюк Г. На перехресті життя та історії / Григорій Костюк // Сучасність. - 1978. - №4. - С. 50-75.

Мацько 2010 - Мацько В. Концепція людини і світу в українській діаспорній прозі XX століття: автореф. дис. ... д-ра філол. наук : 10.01.01/ В. П. Мацько; Київ. нац. ун-т ім. Т. Шевченка. - К., 2010. - 36 с.

Мушинка 1993 - Мушинка М. «Докія Гуменна і iï «Діти...»// Слово і час. - 1993. - №1. - С. 26-35.

Николюк 2009 - Николюк Т. Інтелектуальний інтертекст прози Докії Гуменної : автореф. дис ... канд. філол. наук: 10.01.01 / Тамара Володимирівна Николюк. - Київ : Б.в., 2009. - 19 с.

Погрібний 1994 - Погрібний А. Повернення Докії Гуменної / Анатолій Погрібний // Українське слово. Кн. 2. - К. : Рось, 1994. - С. 444-451.

Рубинштейн 1973 - Рубинштейн С. Проблемы / С. Л. Рубинштейн. - М. : Педагогика, 1973. - 424 с.

Сорока 2003 - Сорока П. Докія Гуменна. Літературний портрет. Тернопіль: Арій, 2003. - 496 с.

Ткачук 2005 - Ткачук М. Наратор-медіум у прозових творах Юрія Федьковича // Наративні виміри літератури. Матеріали міжнародної конференції з наратології / Микола Ткачук // Studia methodologica. Вип. 16. Тернопіль : Редакційно-видавничий відділ ТНПУ, 2005. - С. 148-155.

Шерех 1993 - Шерех Ю. Скарби, якими володіємо // Сучасність. - 1993. № 6. - C. $147-158$.

Bruner 1987 - Bruner J. (1987). Life as Narrative / Jerom, Bruner // Social Research, 54 (1), p. 11-32. 